\title{
Blasts 50 Percent or More of Bone Marrow Nucleated Cells
}

National Cancer Institute

\section{Source}

National Cancer Institute. Blasts 50 Percent or More of Bone Marrow Nucleated Cells. NCI Thesaurus. Code C138065.

A semi-quantitative microscopic finding indicating that greater than or equal to 50 percent of the nucleated cells in a bone marrow sample are immature mononuclear cells. 